Rupkatha Journal on Interdisciplinary Studies in Humanities (ISSN 0975-2935), Vol. 10, No. 1, 2018 Special Issue on "Interrogating Cultural Translation: Literature and Fine Arts in Translation and Adaptation" In collaboration with the Department of English, Amrita Vishwa Vidyapeetham Guest-edited by Dr. Hari M G, Amrita Vishwa Vidyapeetham, Coimbatore, India DOI: https://dx.doi.org/10.21659/rupkatha.v10n1.15 Full Text: http://rupkatha.com/V10/n1/v10n115.pdf

\title{
Contemporary Contextualization of Paanchali and Penelope through Chitra Banerjee's The Palace of Illusions and Margaret Atwood's The Penelopiad
}

\author{
Monali Bhattacharya ${ }^{1} \&$ Ekta Srivastava² \\ ${ }^{1}$ Associate Professor in English, Humanities \& Social Sciences, Jaypee Institute of \\ Information Technology, Noida. ORCID: 0ooo-0oo3-0534-0007. \\ Email: monali.bhattacharya@jiit.ac.in \\ ${ }^{2}$ Assistant Professor in English, Humanities \& Social Sciences, Jaypee Institute of \\ Information Technology, Noida. ORCID oooo-0002-0745-3083. \\ Email: ekta.srivastava@jiit.ac.in
}

Received December 23, 2017; Revised January 30, 2018; Accepted February 4, 2018; Published February 14, 2018.

\begin{abstract}
Females have always been the silent, voiceless and the subaltern sex, but when it comes to assigning some place to these poor, inferior sexes, then they are at the receiving end of the blame-game of the society in history, if at all they are to be given a place. Two such females spoken of, in history likewise are Draupadi in East and Penelope in West, the wives of the greatest heroes of mankind. This paper attempts to study the lives of these two representative ladies of east-west through analysis of their universal femalehood in characterization as done by writers Margaret Atwood and Chitra Banerjee Divakaruni in The Penelopiad and The Palace of Illusions respectively. This paper further tries to assess how the experiences of these at different times and places still remain the cup of tea for today's women everywhere. Finally this paper seeks to establish the contemporary relevance of these two characters through the fact that these two heroines of history were not the 'second sex', rather were very compassionate, loving, intelligent human beings and very able statesmen with all the qualities of good leadership, team coordination and strategic competencies for being successful in life, who could be seen as our torchbearers in twenty first century life as well.
\end{abstract}

Keywords: Female, Paanchali, Penelopiad, $21^{\text {st }}$ century woman.

\section{Introduction:}

Ages may pass, landscapes may change but human soul with all its passions, tribulations, cravings and even manipulations, remains unchanged. Hence literature, which is the record of its time, most of the times, remains timeless and immortal thereby creating classics that remain significant

(c) AesthetixMS 2018. This Open Access article is published under a Creative Commons Attribution Non-Commercial 4.0 International License (http://creativecommons.org/licenses/by-nc/4.0/), which permits non-commercial re-use, distribution, and reproduction in any medium, provided the original work is properly cited. For citation use the DOI. For commercial re-use, please contact editor@rupkatha.com. 
and relevant forever, everywhere. They are rediscovered, and their meanings re-negotiated and reinterpreted time and again.

Hans-Georg Gadamer, one of the most important exponents of modern hermeneutics, delineated the dialogic relationship between text and interpreter perhaps in one of the best possible ways: 'the classical is what is preserve precisely because it signifies and interprets itself: i.e., that which speaks in such a way that it is not a statement about what is past, a mere testimony to something that still needs to be interpreted, but says something to the present as if it were said specially to it. What we call 'classical' does not first require the overcoming of historical distance, for in its own constant communication it does overcome it. The classical, then, is certainly 'timeless', but this timelessness is a mode of historical being' (Gadamer 1975: 257). Gadamer's student, Hans Robert Jauss, has taken this emphasis on the interplay between the horizons of text and reader to a new level in his 1967 lecture at the University of Constance, proposing a new form of what he called Rezeptionsästhetik, or 'poetics of reception,' where the focus is to be placed as much upon the aesthetic response of the reader as the rooted historicity of the original text: "in the triangle of author, work and reading public the latter is no passive part, no chain of mere reactions, but even history-making energy. The historical life of a literary work is unthinkable without the active participation of its audience'. (Jauss \& Benzinger 1970: 8).

As in her book 'The Myths and Me', Atwood also points out that "Myths can be used-as they have been so frequently-as the foundation stones for new versions, new renderingsrenderings that have, in turn, their own contexts, that find their meanings within their own historical moments".(36) Two such novels are Chitra Banerji Divakaruni's The Palace of Illusions and Margaret Atwood's The Penelopiad narrated by Paanchali and Penelope respectively. Divakaruni and Atwood have tried to retell the epics of The Mahabharata and The Oddyssey through Paanchali and Penelope, the respective wives of the protagonists in these. Their lives, expectations, various situations are relevant even today. There exists a very close affinity between the $21^{\text {st }}$ century woman and the multi-talented, multi-tasking Draupadi and Penelope, thereby driving Divakaruni and Atwood to rewrite the classics through the lens of female.

As Gayatri Chakravorty Spivak writes, "The only way I can see myself making definitions is in a provisional and polemical one: I construct my definition as a woman not in terms of a woman's putative essence but in terms of words currently in use. 'Man' is such a word in common usage." (Spivak 495).

The classics of Mahabharata and that of Odyssey have been the driving forces for creating myths and cultural outlook of East \& West respectively for ages. As Black points out:

"Mahabharata is one of the defining cultural narratives in the construction of masculine and feminine gender roles in ancient India, and its numerous tellings and retellings have helped shape Indian gender and social norms ever since“" (Brodbeck/Black 11).

The character of Draupadi has always been that of eternal enigma and as Nair says "in most constructions of Draupadi, in both literary and non-literary texts, she is seen as a victim of patriarchy" (153), Divakaruni has made her as the voice of Female Sensibility.

Same can be said for Odyssey and various characters associated with it. Helen has epitomised beauty for centuries while Penelope is only remembered as the waiting wife. Odyssey is the 'Real Man: intelligent and heroic' capable of warding all challenges inspiring legends after legends through centuries. But if we read both these texts from post-structuralism \& postmodernist viewpoint, we would find that every character could be created as central character shaping various events which have universal significance for all ages and lands. This is what 
Margaret Atwood and Chitra Bannerjee Divakaruni have done while spinning the tales of Penelope and Draupadi from female perspective in The Penelopiad and The Palace of Illusions respectively.

\section{Penelopiad- An Outline:}

In The Penelopiad, Penelope reminisces on the events during the Odyssey, life in Hades, Odysseus, Helen, and her relationships with her parents. A chorus of the twelve maids, whom Odysseus believed were disloyal and whom Telemachus hanged, interrupt Penelope's narrative to express their view on events. The maids' interludes use a new genre each time, including a jump-rope rhyme, a lament, an idyll, a ballad, a lecture, a court trial and several types of songs. The novel recaps Penelope's life in hindsight from 21st century Hades; she recalls her family life in Sparta, her marriage to Odysseus, her dealing with suitors during his absence, and the aftermath of Odysseus' return. She discusses her relationship with parents to as to how her father became overly affectionate after attempting to murder her and her mother was absentminded and negligent but sows the seeds of survival in her mind.

"Water does not resist. Water flows. When you plunge your hand into it, all you feel is a caress. Water is not a solid wall, it will not stop you. But water always goes where it wants to go, and nothing in the end can stand against it. Water is patient. Dripping water wears away a stone. Remember that, my child. Remember you are half water. If you can't go through an obstacle, go around it. Water does." (43).

At fifteen, Penelope is married to Odysseus, and is happy with him; even though he is mocked behind his back by Helen and some maids for his short stature and lesser developed home, Ithaca. The couple break with the tradition by moving to the husband's kingdom. In Ithaca, neither Odysseus' mother Anticleia, nor his nurse Eurycleia, like Penelope but eventually Eurycleia helps Penelope settle into her new role and becomes friendly, though often patronising. Shortly after the birth of their son, Telemachus, Odysseus is called to war, leaving Penelope to run the kingdom and raise Telemachus alone. News of the war and rumours of Odysseus' journey back sporadically reach Ithaca and with the growing possibility that Odysseus is not going to return, an increasing number of suitors move in to court Penelope. Convinced the suitors are more interested in controlling her kingdom than loving her, she stalls them but fears violence at an outright denial of their marriage proposal. So she announces that she would make her decision on who to marry once she has finished weaving her father-in-law's shroud. She enlists twelve maids to help her unravel the shroud at night and spy on the suitors. Odysseus eventually returns but in disguise. Penelope recognises him immediately but instructs her maids not to reveal his identity.

"No sooner had I performed the familiar ritual and shed the familiar tears than Odysseus himself shambled into the courtyard [...] dressed as a dirty old beggar. [...] I didn't let on I knew. It would have been dangerous for him. Also, if a man takes pride in his disguising skills, it would be a foolish wife who would claim to recognize him: it's always an imprudence to step between a man and the reflection of his own cleverness." (135-137)

After the suitors are massacred, Odysseus instructs Telemachus to execute the maids who he believes were in league with them. Twelve are hanged while Penelope sleeps. Afterwards, Penelope and Odysseus tell each other stories of their time apart, but on the issue of the maids 
Penelope remains silent to avoid the appearance of sympathy for those already judged and condemned as traitors.

During her narrative, Penelope expresses opinions on several people, addresses historical misconceptions, and comments on life in Hades. She is most critical of Helen whom Penelope blames for ruining her life. Penelope identifies Odysseus' specialty as making people look like fools and wonders why his stories have survived so long, despite being an admitted liar. She dispels the rumour that she slept with Amphinomus and the rumour that she slept with all the suitors and consequently gave birth to Pan.

Between chapters in which Penelope is narrating, the twelve maids speak on topics from their point-of-view. They lament their childhood as slaves with no parents or playtime, sing of freedom, and dream of being princesses. They contrast their lives to Telemachus' and wonder if they would have killed him as a child if they knew he would kill them as a young man. They blame Penelope and Eurycleia for allowing them to unjustly die. In Hades, they haunt both Penelope and Odysseus.

\section{The Palace of Illusions- An Overview:}

Paanchali is a name which every Indian would have heard since childhood. She is the central female character in India's mythological magnum opus 'Mahabharata'. All the names of the various characters of Mahabharata have metaphorical connotations and have been replicated as names of men and women across generations in India, except for the ones associated with wrong doers like Shakuni or Dhritarashtra. Even female characters (though there are not many) like Kunti, Gandhari or Urvarshi do not find their names in girls of other generations. But ironically, Draupadi, the central female character or any of her other calling names like Paanchali never have found acceptance in India as to be revered or replicated. Though with full sympathy, generations of readers in India have always seen her somewhere responsible for mass destruction or a lady having five husbands, with not so good a fate. None have cared to understand her as 'human'. Divakaruni attempts to tell the story of Mahabharata and her tale from her viewpoint in The Palace of Illusions. She chronicles Paanchali's life since birth, her feelings of being born as sibling of Dhrishtadyum - the wanted child, her excursions into childhood pranks which were beyond limits of feminity, her yearning to learn and question like intelligent males, but always reminded of her girlhood by her nanny etc. Her accepting the fate of being the wife of five brothers, because of mistakes done by her husbands, her secret liking for mysterious Karna, her systematic taking over the reins of household control from her Mother-in Law all find a place in this book. But what makes it different is the narrative of re-construction of Hastinapur undertaken by Paanchali, the Queen after Kurukshetra war and various schemes and mechanisms of Paanchali to empower the war widows by providing training and vocational opportunities in the kingdom. Divakaruni has shown Paanchali as an intelligent, shrewd, compassionate and a loving human being as well as an able statesman in her limited role. During the narrative, Paanchali shares with her readers various yearnings she had or her insights into life with each experience as particularly her references to her educational set-up is very fresh approach on the subject of Gender training: After being allowed to sit in with her brother Dhri and undergoing lessons she feels that this kind of education was "making me too hard-headed and argumentative, too manlike in my speech" ( 23) and at one point she even says that "Each day I thought less and less like the women around me" (26).Infact the ending narrative very suitably complements with what Gender theorist Judith Butler says about 'Performative Roles' being enacted by both the sexes as a result of social 
pressures. Paanchali at the end says what females might be feeling but not allowed to voice or go beyond their performative role of being a woman:

"Perhaps that has always been my problem, to rebel against the boundaries society has prescribed for women. But what was the alternative? To sit among bent grandmothers, gossiping and complaining, chewing on mashed betel leaves with toothless gums as I waited for death? Intolerable! I would rather perish on the mountain. [...], my last victory over the other wives [...]. How could I resist it? (343-44)

"Throughout the narrative Divakaruni has her heroine ponder on the inevitability of fate, the discrepancy between the perception of others and her self-image. The central tension exists between her desire for independence and the attempts to please and conform, which is increased by recurring confrontations with gender differences“. ( Singh, 128)

\section{Contemporary Relevance of Paanchali and Penelope:}

We should never forget that these immortal ladies of East and West were also mortals once, and the way they transcended their worldly problems can guide the $21^{\text {st }}$ century woman whose situation is not much different than theirs in many ways. In fact till date Penelopes and Paanchalis are trying to survive in the man's world for ages. Infant Penelope is nearly drowned by her paranoid father because of the oracle announcing her to weave her father's shroud, while Draupadi is the unwanted child and has to lead a lonely childhood as she herself narrates in The Palace of Illusions:

A gaunt, glittering man walked toward my brother and me as we stood hand in hand. He held out his arms - but for my brother alone....Only my brother that he wanted....We clung together so stubbornly that my father was forced to pick us both together I didn't forget that hesitation...I couldn't forgive him that initial rejection. (6)

Not all the women till $21^{\text {st }}$ century have been as lucky as Penelope to survive death. Especially in developing countries like India, female infanticide continues to rock the world of women. While the ones who survive feel the same pangs as Draupadi with not everyone enjoying the companionship of Dhrishtadyumna and Krishna as she does.

As the child grows, she has to work on her biggest assets - Beauty and Fair Skin. Since ages, it has remained a must for every woman. Today we are luckier to have a range of fairness creams in the market competing against one another to provide fairer and glowing skin within a fortnight. But Penelope and Paanchali undergo initial public rejection and psychological aberrations with the former always being ridiculed by Helen and facing comparisons with her beautiful cousin, while Paanchali being 'severely dark skinned' tells us about her ordeals in The Palace of Illusions :

In a society that looked down its patrician nose on anything except milk-and-almond hues, this was considered most unfortunate, especially for a girl. I paid for it by spending hour upon excruciating hour being slathered in skin-whitening unguents and scrubbed with numerous exfoliants by my industrious nurse. (Divakaruni 8) 
Penelope opens her narration at Hades wherein she and her cousin Helen lead their lives now. She tells us how Helen wanders to the earth and brings news to her about new inventions of beautification in The Penelopiad.

It was through her that I learned about patches, and sunshades and bustles and highheeled shoes, and girdles and bikinis. Even with my limited access, I can see that the world is just as dangerous as it was in my day, except that the misery and suffering are on a much wider scale. As for human nature, it's as tawdry as ever. (Atwood 2)

In spite of being condemned as plain Jane, Penelope and Paanchali create a niche for themselves by recognising their self-worth. They do not require Olay for being sung by bards as Draupadi tells us her secret of being accepted as enigmatic \& mesmerising.

"But this time he (Krishna) must have sensed my confused distress, for he added a few words. "A problem becomes a problem only if you believe it to be so. And often others see you as you see yourself." (Divakaruni 9)

Heeding to these words is the key to being accepted by the society as one wants to be as it was to Draupadi, as well as it is very much the door to success.

The adolescent pains of looking beautiful ultimately lead to the altar of marriage since ages. Marriage plays a very crucial role in a women's life, not only bringing in occasional happiness to her but various aftermath tribulations make her stronger and a 'Survivor'. The complex relationship between a mother-in-law and a daughter-in law has been fodder for many theories and movies like monster-in-law. Women are always considered to be melodramatic but then their lives are not much different from the soap operas of saas-bahus. During Penelope's and Paanchali's times also, it was no different, with Penelope facing Anticleia who despises her and torments her every moment and Draupadi being welcomed by a shrewd Kunti who wants to prove her supremacy at every step.

These two rewritten classics help us in understanding the intricacies of female life, her relationships and various behavioural patterns through the lens of female and at least not once through the lens of male. Man has glamorised female, portrayed her as an 'item' of lust and always as the destroyer of the world, the harbinger of the greatest wars. Hence if on one hand, Helen has been accused of the Trojan war and Penelope as being the silent accomplice in murdering of the maids and the suitors in history, then on the other hand, Paanchali has been called 'Kritya' very often, that is the one who brings doom to the clan. She is always seen as the agent for bringing the doom of Kurukshetra. Girls are seldom named Penelope or Draupadi in either west or east and no parent wishes her daughter to have lives like these two. In south India there is a proverb to caution girls - 'AtiKeshiPatiNasha' which means that a woman with long hair spells destruction for her husband. But Atwood and Divakaruni have tried to peep into their lives and their worlds of traumas in balancing the scales of history. Atwood on one hand has rewritten the archetypes of female passivity and victimisation using contemporary ideas of justice while Divakaruni on the other hand, has reinterpreted the role of Draupadi in Mahabharata as being the survivor, ferociously leading her husbands to claim their birthrights of Hastinapur. She has been shown not just as vindictive or vengeance seeking lady only who caused the War of Kurukshetra but also as the loving sister, one of the best wives, camaraderie for whole life, and moreover biggest architect of the lives of women in war ravaged Hastinapur. Paanchali and Penelope have their own ways to survive the harsh world but they teach us in many ways to survive life. 
The retelling by these writers opens up newer vistas of understanding the connotations of the past discourses and negotiates with better interpretations of the same. Rama Nair's words hold true, - The truth of art lies in its power to inscribe new dimensions to reality. (74)

Atwood has created Penelope's world as largely the world of women, and of relationships between women; and none of those relationships are good ones, (Bowman) except for the one with maids who she nurtures since their childhood. This attribute of female society is common till date with saasbahu sagas in India and Monster in Law myths being popular in Hollywood till date.

Being deserted by her husband Odysseus who had to participate in the Trojan War, Penelope dons the role of a single mother raising the naughty Telemachus with the help of Eucleia, the patronising nurse of Oddyseus. Moreover she also has to manage the affairs of the kingdom in the absence of the king. But we have to remember that "The honor and property that Penelope tries to save belong essentially and primarily to Odysseus because as a wife, she has no independent existence. Therefore, her presence is rather that of a deputy and guardian who has to keep everything in the same order as was left by odyssey until his return(Goksen, 245).

With Odysseus being away for so many years, she has to ward off the 12 suitors who all want to marry her for the kingdom. For this she takes the help of the 12 maids, who she trains to spy on the suitors and distract them. Penelope's words for the suitors in The Penelopiad are very much relevant even today: "They were like vultures when they spot a dead cow: one drops, then another, until finally every vulture for miles is tearing up the carcass." (Atwood 110)

She uses every tactic and excuse to keep them at bay, until Odysseus arrives as a beggar so as to inspect her piousness in his absence. Herein also Penelope has to survive the test and that she does using her mental faculties only, as she narrates in The Penelopiad:

No sooner had I performed the familiar ritual and shed the familiar tears than Odysseus himself shambled into the courtyard [...] dressed as a dirty old beggar. [...] I didn't let on I knew. It would have been dangerous for him. Also, if a man takes pride in his disguising skills, it would be a foolish wife who would claim to recognize him: it's always an imprudence to step between a man and the reflection of his own cleverness. (Atwood 135-137)

When Odysseus along with Telemachus publicly hangs the 12 maids and kills the suitors, she has to be the mute spectator to safeguard herself as not being called treacherous. Her woes and her traumas as to how she had survived the lone years warding off the vulturous men shall never be understood by men folk, be it her husband or her son. She is left with no option. Moreover, double standards between genders and classes have been the norm since time unknown. Odysseus could commit adultery with Circe but Penelope is supposed to be super human, never nurturing such thoughts in her bosom.

Paanchali has always been condemned as being the sole cause of Kurukshetra war but her tribulations have never been sympathized with. Being ravaged between her feelings for the 'man with ancient eyes' and the dream of having her own palace on one side and the harsh reality of being the wife of five men and their partner in lifelong misery on the other hand, Paanchali has often been seen as temperamental, manipulative and haughty. But she embodies the female tirade of being disgraced as an instrument of lust in the man's world, whether as the property of the husband to be sold at his will or being called as 'Vaishya' by the men who themselves behave like 'vahshis' to make her so. Hence till date, Dushhasans and Keechaks are always trying to rape Draupadis in every land. But Paanchali instead of being the mute victim of such humiliation 
chooses the harsher way of punishing the culprits. Being made physically weak by the Almighty, she has to survive this man's world with the help of man only. She leaves no stone unturned to get her revenged through her husbands' as she says in the novel when she goes to the forest for thirteen years:

"I stitched discontent onto my features and let my hair fall, matted and wrathful, around my face. Each day as I served their meals, I reminded the Paandavas of how they'd failed me and what I'd suffered as a result in Duryodhan'ssabha. Each night I recited the taunts of the Kauravas so that they stayed fresh in their minds....Recognizing Bheem's weakness, I took advantage of it. I wept more loudly when he was around....Ultimately at Kurukshetra he would kill and kill again, going against the laws of righteous war not for victory or glory but for my sake." (Divakaruni 199-213)

To survive in the man's world, to keep her honour intact, woman has to resort to shrewd mannerisms and uncanny ways, be it Penelope or Paanchali but only because of circumstances. Paanchali embodies this strife of woman in a very significant way but being instrumental in bringing havoc to the world does not mean that she is sans sentiment. She has to lose her dearest brother, her sons and be the cause of death of her heartfelt love in the end. She also has to thread together the remnants of the devastated kingdom of Hastinapur with widowed women and fatherless children. With the help of her Mothers in Law, Sisters in Law and daughter in law, she dispenses justice to the women and reconstructs their lives. By selling the jewellery, artefacts and palace furnishings, she sets up destitute in their homes and helps them in buying merchandize to start business for them. Hence, because of Paanchali's endeavours, with the passage of time, women's market becomes a flourishing centre of trade in the city. The ladies who show interest in learning are encouraged by Paanchali to become tutors for girls and young boys. But more importantly she also embodies what today's women feel when they have crossed the roads of feminity to becoming females. As Smriti Singh puts it:

Inspired by Sikandhi's sex change as the ultimate liberation from the restrictions of womanhood, Panchaali is aware from the start that: "I, too, would cross the bounds of what was allowed to women" (51). As shown above, her behaviour frequently transgresses the boundaries of traditional femininity, e.g. her outspokenness, her education and her polyandrous marriage. Furthermore, she fails to display a strong attachment to her children, valuing her independence higher than motherhood. To be at the side of her husbands, she leaves her sons behind, barely recognizing them years later. Draupadi challenges the traditional formulations of what a woman and wife should be. Though she doesn't switch genders like Shikhandi, she has definitely moved away from traditional femininity towards vengeance which is one of the important strands in reading this epic through feminist lenses. (Singh, 129-130)

\section{Conclusion:}

History has always seen Penelope and Paanchali as the cause of mass slaughter, but their reasons for resorting to such behaviour has always remained unspoken. Being born into the passive gender, they try to salvage their bruised, tarnished honour in the cruel, ruthless world of man. In order to survive in the man's world with dignity, they have to be manipulative at times, but are never treacherous as their counterparts of the opposite gender. In their eternal journey of womanhood, they climb the stairs of grace and honour through sheer strong will power, self reliance and faith in themselves and in this process show their managerial skills of team coordination, team leadership, strategic and communicative competencies and finally their able 
administrative skills. They never compromise with their self respect, though the world is ever willing to tarnish their lives. In their journey they are every woman of every age in every land. They embody the eternal sufferings of female but also prove to be torch bearers of survival for them in the male world. In fact it depends on the 'Horizons of Expectations' of readers who can decide at whether to take and understand the stories in positive or negative light, a good example of which being the observation of a contemporary critic of Atwood, who says for The Penelopiad:

It is Penelope's voice speaking from the dead which sparks the connection between ancient myth and contemporary reality, for her story is grounded in the domestic details of her life as daughter, wife and mother, and then as a queen who has to manage her husband's estates on the island of Ithaca for twenty years single-handed. (As Atwood has remarked, she must have done a great many other things besides the weeping and weaving which Homer attributed to her.) Penelope comments on her problems with her mother-in law and Odysseus's old nurse, Eurycleia ('She was always Odysseus's biggest fan,' p. 106), on Odysseus's desertion and on her difficulties as a single mother with their teenage son Telemachus: 'Whether ancient Greece or the contemporary world, it's all just the usual family dynamics. Remove the fancy language, and that's what it is. (Dixon R12).

It is for the reader to decide whether he sees family as kernel of society or a very small entity in the social fabric. Likewise the perception towards understanding would alter.

As Helena Cuxious points out in her essay 'The Laugh of Medusa”:

I shall speak about women's writing about what it will do. Woman must write herself: must write about women and bring women to writing, from which they have been driven away as violently as from their bodies- for the same reasons, by the same law, with the same fatal goal. Woman must put herself into the text - as into the world and into history - by her movement. (875)

Through the Penelopiad and The Palace of Illusions, Atwood and Divakaruni have at least given a voice to the female wherein Penelope and Paanchali retell their stories through the female lens of perspective as their age old incidents have great contemporary relevance. Hence these immortal creations of classics have been and need to be recreated time and again to give newer meanings to our ordinary lives in the $21^{\text {st }}$ century and thereafter as well.

\section{References}

Atwood, Margaret. (2005) 'ThePenelopiad'. Canada: Knopf

Atwood, Margaret '(2005), The Myths and Me', Read: Life with Books (Random House) 6.1 p-36

Black, B. (2007) "Eavesdropping on the Epic: Female Listeners in The Mahabharata." (Eds.) S. Brodbeck and B. Black Gender and Narrative in the Mahabharata.. London: Routledge, 53-78

Bowman, Laurel. (2006) "Rewriting Helen: The Penelopiad" CAC Toronto

Cixous, Helen. 1976. “The Laugh of the Medusa.” Translated by K. Cohen and P. Cohen.Signs.Vol. 1. No.4: 875893

Divakaruni, Chitra Banerjee.(2008) 'The Palace of Illusions'. India: Picador

Gadamer, H.-G., (1975).Truth and Method. London: Sheed and Ward. 
Gökçen, Nilsen. (2009) The Past to Remember and the Past to Forget: Rewfiting, Memory and Nostalgia in The Penelopiad. 'Memory \& Nostalgia' Ed.Silku et al. Turkey: Ege University Press, pp. 245

Guy Dixon, 'A Desperate Housewife in Ancient Greece: Interview with Margaret Atwood'. The Globe and Mail: Review, 22 October 2005, R12.

Jauss, H.R. \&Benzinger, E., (1970).'Literary history as a challenge to literary theory.' New Literary History, 2(1), pp. 7-37.

Nair, K. (2011) "Agency, Narrativity, Gender in Chitra Banerjee Divakaruni's The Palace of Illusions." Language in India.

Nair, R. (2007) The Concept of Identity in Indian Immigrant Women in America: A LiteraryPerspective. Studies in Post Colonial Literature Ed. Khan, M.Q., and Bijay Kumar Das.New Delhi: Atlantic Publishers.

Singh, Smriti. (2015), Revisiting the Mahabharata: Draupadi's Voice in Divakaruni's 'The Palace of Illusions. Ed Praisler. "Cultural Intertexts".Journal of Literature, Cultural Studies and Linguistics. culturalintertexts.webnode.com

Spivak, Gayatri C. "Feminism and Critical Theory.” Modern Criticism and Theory: A Reader.Ed. David Lodge et.al. Delhi: Pearson Education, Inc. 2007. 495. Print.

\begin{abstract}
About the Authors
Dr. Monali Bhattacharya is presently working as Associate Professor in the Department of Humanities \& Social Sciences at Jaypee Institute of Information Technology, Noida-India. She has done her MA (English) \& Ph.D (Comparative Literature) from University of Allahabad. Her areas of interest are interdisciplinary studies in Literature, Comparative Literature, Gender Studies, Translation Studies, Cultural Studies and Film Studies. She has successfully supervised six Ph.d scholars (English Literature) and 13 M.Phil Dissertations in ELT under her supervision till date. She has published numerous papers and two books apart from having edited University journals and magazines at Allahabad University and Banasthali University, Rajasthan. ORCID idorcid.org/oooo-0003-0534-0007. Email: monali.bhattacharya@jiit.ac.in
\end{abstract}

Dr. Ekta Srivastava is presently working as Assistant Professor in the Department of Humanities \& Social Sciences at Jaypee Institute of Information Technology, Noida-India. She has done her MA (English Literature) \& Ph.D (English Literature-Feminine Sensibility) from University of Allahabad. Her areas of interest are interdisciplinary studies in Literature, Comparative Literature, Professional Communication, Cross-Cultural Communication, Adaptations. ORCID idorcid.org/oooo-0002-0745-3083.Email:ekta.srivastava@jiit.ac.in 